\title{
Correlation between Carbon Dioxide Production and Mean Arterial Blood Pressure in Fluid Response in Mechanically Ventilated Patients
}

\author{
ELHASAB A. EL-GNAIDY, M.Sc.; LOBNA M. ABO EL-NASR, M.D.; SABRY M. AMEEN, M.D. and \\ MOHAMMED S. ABD EL-GHAFAR, M.D. \\ The Departments of Anesthesia, Surgical Intensive Care and Pain Medicine, Faculty of Medicine, Tanta University
}

\begin{abstract}
Background: Volume expansion through fluid administration is one of the simplest approaches for initial treatment of hemodynamic instability. In the Intensive Care Unit (ICU) a newly available technique called volumetric capnography (Vcap) allows measurement of carbon dioxide production (VCO2) on a regular basis at the bedside.
\end{abstract}

Aim of Study: The aim of the study was to evaluate $\mathrm{VCO} 2$ as an endpoint predictor for fluid resuscitation in mechanically ventilated patients.

Methods and Material: This prospective cohort study was carried out on 70 patients in Tanta University Hospitals at surgical ICU from August 2017 till August 2018. All patients included in the study were on controlled mechanical ventilation with tidal volume $6-8 \mathrm{ml} . \mathrm{kg}$ ideal body weight. Wide bore intravenous lines were inserted and patients were completely sedated and monitored by; pulse oximeter, non-invasive blood pressure monitoring, ECG all connected to monitor (infinium medical-OMNI 111-FL33773-USA). Volumetric capnogram, end tidal capnogram, detected by Y-Piece and sample line connected to (GE Healthcare Finland Oy, E-sCOVX-00Finland). Bispectral Index (BIS) to assess the depth of sedation (should be between 40-60). Intravenous fluids were given after hypotension till MAP $>65 \mathrm{mmHg}$.

Results: There was significant increase in MAP and $\mathrm{VCO} 2$ and significant decrease in HR after fluid resuscitation and there was no significance difference in $\mathrm{BIS}, \mathrm{SpO}_{2}$. There was positive correlation between $\mathrm{VCO} 2$ and MAP with sensitivity of $\mathrm{VCO} 2$ for fluid responsiveness $92 \%$.

Conclusions: $\mathrm{VCO} 2$ and $\mathrm{EtCO} 2$ are good monitoring toolswhichare well correlated with hemodynamic changes, thus can be used as an indicator for fluid responsiveness and endpoint prediction ofresuscitation.

Key Words: fluid responsiveness - Volumetric capnography - $\mathrm{CO} 2$ production $\left(\mathrm{VCO}_{2}\right)-$ Hemodynamics.

Correspondence to: Dr. Elhasab A. El-Gnaidy,

The Department of Anesthesia, Surgical Intensive Care and Pain Medicine, Faculty of Medicine, Tanta University

\section{Introduction}

FLUID administration during and after surgery is a fundamental strategyformaintaining hemodynamic stability. Technology offers different strategies for hemodynamic monitoring and decision making about fluids administration. In particular patients may be divided into fluid-responding patients and non-fluid-respondingpatients [1]. Volume expansion through fluid administration is one of the simplest approaches initial treatments of hemodynamic instability [2]. Although the collective evidence shows the clear relation between impaired peripheral perfusion and mortality, the use of different perfusion indices as a resuscitation target was not adequately investigated. Most of the data concerning the perfusion indices are extracted from observational trials with a few number of randomized controlled trials [3]

Carbon dioxide $\left(\mathrm{CO}_{2}\right)$ produced through tissue metabolism is rapidly excreted from the circulation by the lungs by passive diffusion from the capillaries to the alveoli, and its production approximately matches excretion. Thusmonitoring $\mathrm{CO}_{2}$ could be a useful complementary tool to guide the resuscitation in the early phase of deficit tissue perfusion [4] . In the Intensive Care Unit (ICU) a newly available technique called volumetric capnography (Vcap) allows measurement of carbon dioxide production $\left(\mathrm{VCO}_{2}\right)$ on a regular basis at the bedside. In this technique expired $\mathrm{CO}_{2}$ is plotted against exhaled lung volume. This allows breathby-breath quantification of the volume of lung units [5]. Volumetric capnogram is a noninvasive, safe and easily used. 
The aimof the study is to correlate between VCO2 and Mean Arterial blood Pressure (MAP) and using this principle for prediction of fluid responsiveness and resuscitation.

\section{Material and Methods}

After obtaining the Research Ethics Committee approval (approval code: 31567/05/17) and informed written consentwas taken from patient guardians, a prospective cohort study was carried out in Tanta University Hospitals in surgical ICU from August 2017 till August 2018, 70 patients of both sex, 18-60 years old,on mechanical ventilation (GE-Medical Systems of Egypt-carescape R860Datex-Ohmeda, Inc. 3030 Ohmeda Drive-PO Box 7550-Madison WI53707-7550-Made in USA) with tidal volume $6-8 \mathrm{ml} / \mathrm{kg}$ ideal body weight. Wide bore intravenous lines were inserted and patients were completely sedated. Patients who developed hypotension and were fluid responders were enrolled into the present study and were monitored by pulse oximeter, non-invasive blood pressure monitoring, ECG, connected to monitor (infinium medical-OMNI 111-FL33773-USA), volumetric capnogram, end tidal capnogram, detected by YPiece and sample line connected to (GE Healthcare Finland Oy E-sCOVX-00-Finland) and Bispectral index (BIS) to assess the depth of sedation (should be between 40-60). Refusal of patient guardians, renal, hepatic, respiratory, cardiac, feverish patients and inability to perform Inferior Vena Cava (IVC) ultrasonographywere excluded from the study. Patients were tested for fluid responsiveness and hypovolemia after hypotension by visualization of IVC diameter and calculation of IVC distensibility index, fluid responsiveness is likely if the IVC distensibility $>18 \%$. IVC distensibility $=($ Max diameter-min diameter)/(min diameter) X 100 [6] Patients were resuscitated by IV crystalloid, by giving $4 \mathrm{ml} . \mathrm{kg}^{-1}$ bolus within 15 minutes and reevaluation done every 5 minutes. If the target goal not reached another volume would be given with maximum fluid up to $30 \mathrm{ml} . \mathrm{kg}^{-1}$ within 3 hours till reaching the target goal (MAP $\geq 65 \mathrm{mmHg}$ ).

If the target goal wasn't achieved in the first 3 hours, the patients were excluded from the study. But resuscitation should be continued.

Measurements: Assessment is done at baseline andevery 10min for the following: MAP, peripheral oxygen saturation ( $\mathrm{SpO} 2)$, Heart Rate (HR), end tidal carbon dioxide, $\mathrm{VCO} 2$ and $\mathrm{BIS}$ values.
Sample size calculation and statistical analysis:

Sample size and power analysis were performed using Epi-info. Statistical softwarepackage created by WHO and CDC, Atlanta, Georgea, USA version [7]. The criteria used for sample size and power analysis was as follows: 95\% confidence limit, level of correlation of predictable variable at 90 with a margin of error not more than 7\%. (N>61).

Statistical presentation and analysis of the present study was conducted SPSS V.25. Using numerical data was presented as mean and Standard Deviation (SD) and compared by $t$-test. Categorical data was presented as frequency and percentage. Pearson correlation was done between $\mathrm{VCO} 2$ and MAP. $p$-value $<0.05$ was considered significant.

\section{Results}

This study was conducted on 70 patients of both sex; 46 males $(65.7 \%)$ and 24 females (34.3\%) with age ranged between (18-60 years) with a mean value of $(40.26 \pm 13.5) \mathrm{y}$. In addition, patient's height ranged between (1.65-1.85) $\mathrm{m}$ with a mean value of $(1.74 \pm 0.042) \mathrm{m}$, and weight ranged between $(65-93) \mathrm{kg}$ with a mean value of $(78.76 \pm 6.96) \mathrm{kg}$ with BMI ranged between $\left(21-32 \mathrm{~kg} / \mathrm{m}^{2}\right)$ with a mean value of $(26.06 \pm 2.67) \mathrm{kg} / \mathrm{m}^{2}$ (Table 1).

\section{Enrollment}

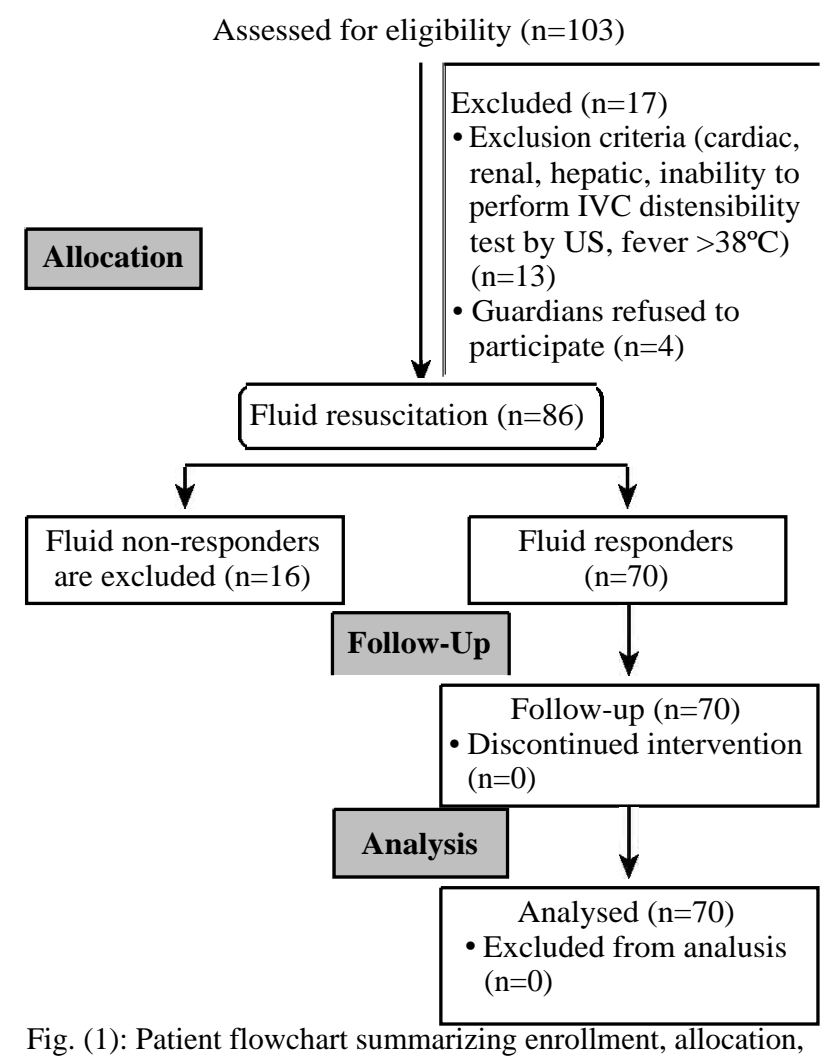
follow-up and analysis in the study. 
Table (1): Demographic data and patients characteristics.

\begin{tabular}{lll}
\hline & Range & Mean \pm S.D \\
\hline Age $(\mathrm{y})$ & $18-60$ & $40.26 \pm 13.50$ \\
Weight $(\mathrm{kg})$ & $65-93$ & $78.76 \pm 6.96$ \\
Height $(\mathrm{m})$ & $1.65-1.85$ & $1.74 \pm 0.42$ \\
BMI $(\mathrm{kg} / \mathrm{m} 2)$ & $21-32$ & $26.06 \pm 2.67$ \\
& $\mathrm{~N}$ & $\%$ \\
Sex: & 46 & 65.7 \\
$\quad$ Male & 24 & 34.3 \\
Female & & \\
\hline
\end{tabular}

There was significant increase in MAP endpoint as compared to baseline Fig. (2). There was significant decrease in HR endpoint as compared to baseline Fig. (3). There was significant increase in $\mathrm{VCO}_{2}$ endpoint compared to baseline (Table 2).

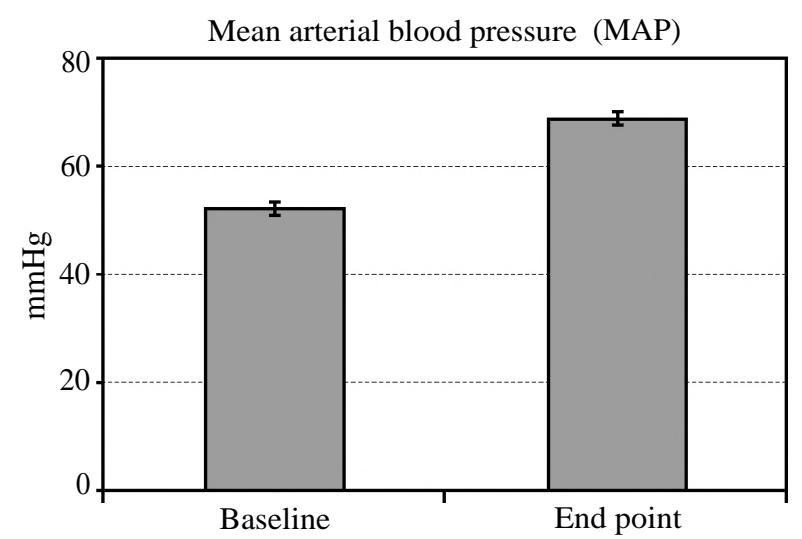

Fig. (2): Comparison between mean values of MAP baseline and endpoint.

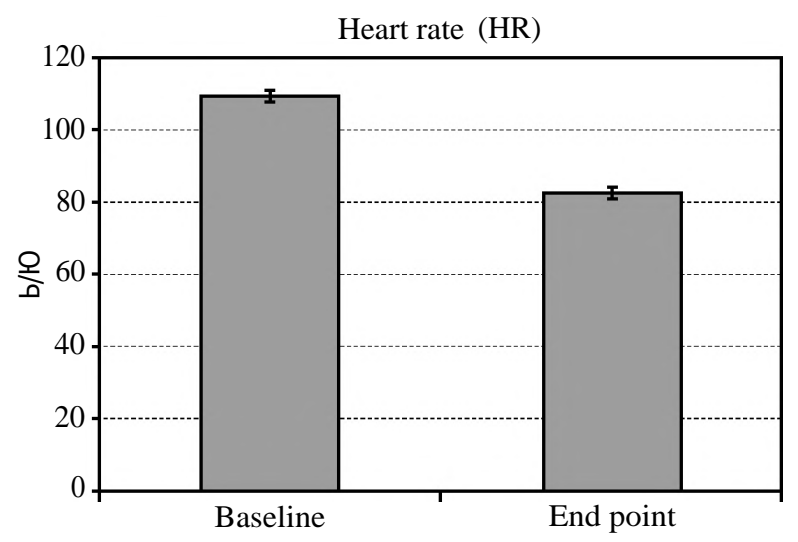

Fig. (3): Comparison between mean values of HR (b/min) baseline and endpoint.

Table (2): Changes in mean values of carbon dioxide production measured by volumetric capnogram $\left(\mathrm{VCO}_{2}\right)$ $(\mathrm{ml} / \mathrm{min})$ baseline and endpoint.

\begin{tabular}{llc}
\hline $\mathrm{N}(70)$ & Baseline & End point \\
\hline Range & $105-388$ & $118-415$ \\
Mean \pm SD & $212.93 \pm 66.83$ & $232.36 \pm 66.34$ \\
$p$-value & \multicolumn{2}{c}{$0.038^{*}$} \\
\hline
\end{tabular}

There was no significant change in values between $\mathrm{SpO}_{2}$ andBIS endpoint as compared to baseline.

There is positive significant correlation $(p=$ 0.044 ) between MAP and $\mathrm{VCO}_{2}$ with $r=0.386$ Fig. (4). $\Delta \mathrm{VCO}_{2}$ was $19.43 \pm 6.78 \mathrm{ml} / \mathrm{min}$ and $\Delta \mathrm{MAP}$ was $17.0 \pm 5.83 \mathrm{mmHg}$. Sensitivity of $\mathrm{VCO}_{2}$ to predict fluid responsiveness was $92 \%$.

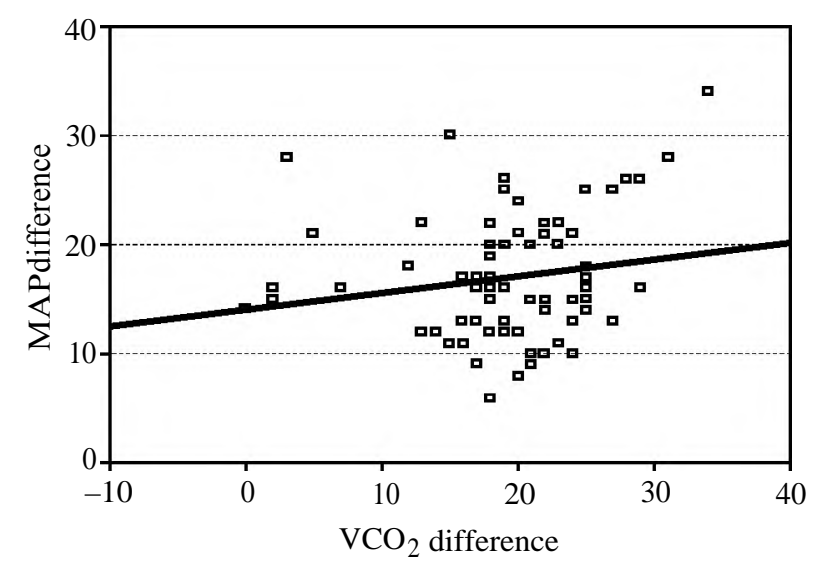

Fig. (4): Correlation between mean arterial blood pressure $(\mathrm{mmHg})$ and carbon dioxide production measured by volumetric capnogram $\left(\mathrm{VCO}_{2}\right)(\mathrm{ml} / \mathrm{min})$.

\section{Discussion}

Fluid administration is the first-line therapy in patients with acute circulatory failure. The main goal of fluid administration is to increase the cardiac output and ultimately the oxygen delivery. Nevertheless, the decision to administer fluid or not should be carefully considered, since half of critically ill patients are fluid unresponsive, and the dangerous effects of fluid overload clearly documented. Thus, except at the initial phase ofhypovolemic or septic shock, where hypovolemia is constant and most of the patients responsive to the initial fluid resuscitation, it is of importance to test fluid responsiveness before administering fluids in critically ill patients [7].

Hemodynamic monitoring is essential to test fluid responsiveness and thus to prevent administration of fluid in preload unresponsive patients. Predicting fluid responsiveness may help ICU physicians to decide whether or not to administer intravenous fluids but also whether or not to stop fluid infusion. It thus allows clinicians to better individualize their treatment by selecting patients who can benefit from volume expansion and preventing fluid infusion in those who would be fluid unresponsive and who may experience harmful effects, such as development or worsening tissue oedema [8]. 
In the ICU a newly available technique called volumetric capnography (Vcap) allows measurement of $\mathrm{VCO} 2$ on a regular basis at the bedside. In this technique expired $\mathrm{CO}_{2}$ is plotted against exhaled lung volume. This allows breath-by-breath quantification of the volume of lung units [5].

The approach of the current studyto correlate between $\mathrm{VCO} 2$ and MAP in fluid responder patients which developed hypotension on mechanical ventilation. Whether we can depend on volumetric capnogram to end resuscitation or not.

There is positive significant correlation between MAP and with sensitivity of $\mathrm{VCO} 2$ to predict fluid responsiveness was $92 \%$.

This study came in agreement with Garnett et al., [9] they demonstrated that change in the $\mathrm{EtCO}_{2}$ value was often the first clinical indicator that ROSC had occurred. VCO2, alveolar ventilation, and perfusion together affect the EtCO 2 concentration. when $\mathrm{CO}_{2}$ productionand ventilation remains constant EtCO 2 depends on perfusion. So, when $\mathrm{CO}$ increased (after ROSC) EtCO 2 also increased. They suggested that end-tidal $\mathrm{CO} 2$ monitoring may provide clinically useful information that can be used to guide therapy during Cardiopulmonary Resuscitation (CPR).

Furthermore, thisstudy came in agreement with study done by Shibutani et al., [10], in all episodes of hemodynamic changes, there was a significant linear correlation between the percent decrease in $\mathrm{EtCO} 2$ and the percent decrease in cardiac output and that is explained by decreased delivery of $\mathrm{CO} 2$ to the lung by decreased pulmonary blood flow may be a factor. When tidal volume was kept constant, the changes occurring in PetCO 2 and $\mathrm{VCO} 2$, following hemodynamic changes were parallel. they concluded that changes in EtCO 2 quantitatively reflect changes in cardiac output.

Also, our study came in agreement with Xavier Monnet et al., [11] they tested PLR induced changes on hemodynamics and its relation with end tidal carbon dioxide. Exhaled $\mathrm{CO} 2$ is determined by three factors: The production of $\mathrm{CO} 2$ by cell metabolism, the pulmonary flow (cardiac output) that drives $\mathrm{CO}_{2}$ from the periphery to the lungs and the ability of the lung to clear the venous blood of $\mathrm{CO} 2$. Thus, if two of the three factors are constant, changes in $\mathrm{EtCO} 2$ might reflect changes of the third. The PLR maneuver induces passive transfer of blood contained in the venous compartment of the lower limband of the abdominal compartmentto the heart and increases the right and left cardiac preload and so increase cardiac output, so in steady state and constant ventilation any EtCO 2 changes are early detectable. They reported that in stable ventilatory and metabolic conditions, changes in $\mathrm{EtCO} 2$ might reflect changes in Cardiac Index (CI). The changes in $\mathrm{EtCO}_{2}$ induced by a PLR test predicted fluid responsiveness with reliability, while the changes in arterial pulse pressure did not. EtCO2 monitoring should thus be regarded as a noninvasive surrogate of CI during PLR when no device is available for measuring CI [11]. Also, this study came in agreement with Kolar et al., [12] who studied 737 cases of out-of-hospital cardiac arrest. End-tidal carbon dioxide levels of more than $(14.3 \mathrm{mmHg})$ after 20 minutes may be used to predict ROSC with accuracy.

Moreover, came in agreement with study done by Pokorná et al., [13] . This study applied EtCO 2 monitoring to out-of hospital resuscitation (ALS) of patients with cardiac arrest. So the study demonstrated that constantly ventilated patients undergoing ALS in out-of-hospital conditions have a significantly higher $\mathrm{EtCO} 2$ of about $10 \mathrm{mmHg}$ after ROSC than before ROSC. Furthermore, came in agreement with this study, Monge Garcia et al., [14] who studied 37 mechanically ventilated patients with acute circulatory failure. The main finding of this study is that, under fixed minute ventilation and assuming a constant tissue $\mathrm{CO} 2$ production, acute changes in partial EtCO 2 pressure during the passive leg-raising maneuver are strongly correlated with changes in cardiac output.

Also this study also came in agreement withAlisha Young et al., [15] who studiedchanges in $\mathrm{EtCO} 2$ and $\mathrm{VCO} 2$. They reported that the delta $\mathrm{VCO} 2$ had greater diagnostic accuracy than EtCO 2 and concluded that dynamic changes in $\mathrm{EtCO} 2$ and $\mathrm{VCO} 2$ may be used as adjunctive indicators of fluid responsiveness in patients without underlying lung disease. Moreover, the present study came in agree with the systematic review done by Edison et al., [16] which aimed to identify whether any level of EtCO2 measured during CPR correlates with ROSC or survival in adults experiencing cardiac arrest in any setting. The available studies provided consistent but low-quality evidence that EtCO2 measurements $\geq 10 \mathrm{mmHg}$, obtained at various time points during CPR, are substantially related to ROSC.

Also this studycame in agreement with Ornato et al., [17] who studied relationship between cardiac output and the EtCO 2. This study carried out on [14] anesthetized, intubated sheep and plotted $\mathrm{EtCO} 2$ against $(\mathrm{CO})$ and concluded that the rela- 
tionship between $\mathrm{CO}$ and $\mathrm{EtCO}_{2}$ is logarithmic. This physiological relationship allows EtCO 2 to be used as a noninvasive, real-time indicator of trends in $\mathrm{CO}$ during low-flow states. If ventilation is kept constant, data from this study predict that a change in $\mathrm{CO}$ should result in a detectable change in $\mathrm{EtCO}_{2}$ as a direct consequence of the change in the ventilation/perfusion relationship. Also, Arnaldo Dubin et al., [18], came in context withthe present study, who studiedthe end tidal $\mathrm{CO} 2$ pressure in the monitoring of cardiac output during canine hemorrhagic shock. The monitoring of sequential changes of $\mathrm{EtCO} 2$, could be a useful adjunct in the management of mechanically ventilated patients.

Also this study came in context with study done by Isserles and Breen [19] which carried out on [5] anesthetized dogs after vena cava interruption. During constant minute ventilation and tidal volume, abrupt reduction in $\mathrm{CO}$ reduces $\mathrm{EtCO} 2$ and $\mathrm{VCO} 2$. They concluded that during the increase in cardiac output, there were significant linear percent increases in PetCO 2 and $\mathrm{VCO} 2$. So, capnography is accepted as an important clinical monitor during anesthesia and intensive care and the measuring equipment is easy-to-use, reliable, and relatively inexpensive. Moreover, came in agreement with the present study, Xiaohua Jin et al., [20]. They anticipated that under the condition of constant ventilation, reductions in EtCO 2 would be related closely to the pulmonary blood flow.

Furthermore, came in agreement with the present study, Dubin et al., [21], who studied the relationship between $\mathrm{EtCO} 2$ andits physiological determinants (cardiac output and others) duringhaemorrhagic shock in six anesthetized dogs mechanically ventilated. EtCO 2 was greatly correlated with $\mathrm{CO}$ and $\mathrm{VCO} 2$. Also came in agreement with the present study, the study done by Idris et al., [22]. The study was to measure EtCO 2 during wellcontrolled, very low blood flow rates under conditions of constant minute ventilation in ten anesthetized, intubated, and mechanically ventilated swine. Minute ventilation was measured and kept constant. Results confirmed that EtCO 2 was significantly correlated with cardiac index.

\section{Conclusions:}

$\mathrm{VCO} 2$ and $\mathrm{EtCO} 2$ are good monitoring tools which are well correlated with hemodynamic changes, thus can be used as an indicator for fluid responsiveness and endpoint prediction ofresuscitation.

\section{Conflicts of interest: Nil.}

Authors' contributions:

All authors had equal role in design, work, statistical analysis and manuscript writing.

\section{References}

1- GUARNIERI M., BELLETTI A., SAGLIETTI F. and BIGNAMI E.: Central Venous Pressure as a Predictor of Fluid Responsiveness: Is this all you need. General medicine, 4: 2-3, 2016.

2- FUNK D.J., JACOBSOHN E. and KUMAR A.: The role of venous return in critical illness and shock-part I: Physiology. Critical care medicine, 41: 255-62, 2013.

3- HASANIN A., MUKHTAR A. and NASSAR H.: Perfusion indices revisited. Journal of Intensive Care, 5: 24, 2017.

4- MALLAT J., LEMYZE M., TRONCHON L., VALLET B. and THEVENIN D.: Use of venous-to-arterial carbon dioxide tension difference to guide resuscitation therapy in septic shock. World Journal of Critical Care Medicine, 5: 47, 2016.

5- VERSCHEURE S., MASSION P.B., VERSCHUREN F., DAMAS P. and MAGDER S.: Volumetric capnography: Lessons from the past and current clinical applications. Critical Care, 20: 184-92, 2016.

6- PADANG R. and MANKAD S.V.: Transthoracic and Transesophageal Echocardiography in Interventional Cardiovascular Catheter-Based Therapy. In: Lanzer P, editor. Textbook of Catheter-Based Cardiovascular Interventions: A Knowledge-Based Approach. Cham: Springer International Publishing, p. 217-44, 2018.

7- JOZWIAK M., MONNET X. and TEBOUL J.L.: Prediction of fluid responsiveness in ventilated patients. Annals of Translational Medicine, 6: 152-61, 2018.

8- BEURTON A., MONNET X. and TEBOUL J.L.: Assessment of Fluid Responsiveness in Patients with Intraabdominal Hypertension. Annual Update in Intensive Care and Emergency Medicine, Springer; 2018. p. 407-15, 2018.

9- GARNETT A.R., ORNATO J.P., GONZALEZ E.R. and JOHNSON E.B.: End-tidal carbon dioxide monitoring during cardiopulmonary resuscitation. J.A.M.A., 257: 512-5, 1987.

10- SHIBUTANI K., MURAOKA M., SHIRASAKI S., KUBAL K., SANCHALA V.T. and GUPTE P.: Do Changes in End-tidal $\mathrm{Pco}_{2}$ Quantitatively Reflect Changes in Cardiac Output? Survey of Anesthesiology, 39: 829-33, 1995.

11- MONNET X., RIENZO M., OSMAN D., ANGUEL N., RICHARD C., PINSKY M.R., et al.: Passive leg raising predicts fluid responsiveness in the critically ill. Critical Care Medicine, 34: 1402-7, 2006.

12- KOLAR M., KRIZMARIC' ${ }^{\prime}$ M., KLEMEN P. and GRMEC S: Partial pressure of end-tidal carbon dioxide successful predicts cardiopulmonary resuscitation in the field: A prospective observational study. Critical care, 12: 11527, 2008.

13- POKORNÁ M., NECAS E., KRATOCHVÍL J., SKRIPSKY' R., ANDRLÍK M. and FRANËK O.: A sudden 
increase in partial pressure end-tidal carbon dioxide (PetCO2) at the moment of return of spontaneous circulation. The Journal of Emergency Medicine, 38: 614-21, 2010.

14- GARCÍA M.I.M., CANO A.G., ROMERO M.G., PINTADO R.M., MADUEÑO V.P. and MONROVÉ J.C.D.: Noninvasive assessment of fluid responsiveness by changes in partial end-tidal $\mathrm{CO} 2$ pressure during a passive legraising maneuver. Annals of Intensive Care, 2: 9-16, 2012.

15- YOUNG A., MARIK P.E., SIBOLE S., GROOMS D. and LEVITOV A.: Changes in end-tidal carbon dioxide and volumetric carbon dioxide as predictors of volume responsiveness in hemodynamically unstable patients. Journal of cardiothoracic and vascular anesthesia, 27: 681-4, 2013.

16- PAIVA E.F., PAXTON J.H. and O'NEIL B.J.: The use of end-tidal carbon dioxide (EtCO 2) measurement to guide management of cardiac arrest: A systematic review. Resuscitation, $123: 1-7,2018$.

17- ORNATO J.P., GARNETT A.R. and GLAUSER F.L.: Relationship between cardiac output and the end-trial carbon dioxide tension. Annals of Emergency Medicine, 19: 1104-6, 1990.

18- DUBIN A., SILVA C., CALVO G., VALLI J., FARIÑA O., ESTENSSORO E., et al.: End-tidal $\mathrm{CO} 2$ pressure in the monitoring of cardiac output during canine hemorrhagic shock. Journal of Critical Care, 5: 42-6, 1990.

19- ISSERLES S. and BREEN P.: Can Changes in End-Tidal $\mathrm{PCO} 2$ Measure Changes in Cardiac Output? Survey of Anesthesiology, 36: 289, 1992.

20- JIN X., WEIL M.H., TANG W., POVOAS H., PERNAT A., XIE J., et al.: End-tidal carbon dioxide as a noninvasive indicator of cardiac index during circulatory shock. Critical Care Medicine, 28: 2415-9, 2000

21- DUBIN A., MURIAS G., ESTENSSORO E., CANALES H., SOTTILE P., BADIE J., et al.: End-tidal CO 2 pressure determinants during hemorrhagic shock. Intensive Care Medicine, 26: 1619-23, 2000

22- IDRIS A.H., STAPLES E.D., O'BRIEN D.J., MELKER R.J., RUSH W.J., DEL DUCA K.D., et al.: End-tidal carbon dioxide during extremely low cardiac output. Annals of Emergency Medicine, 23: 568-72, 1994.

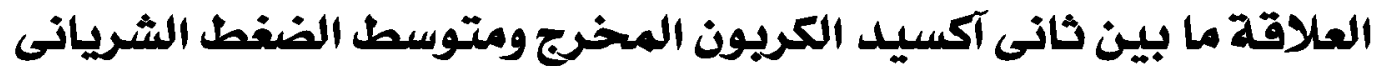

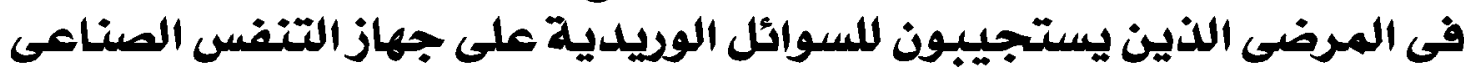

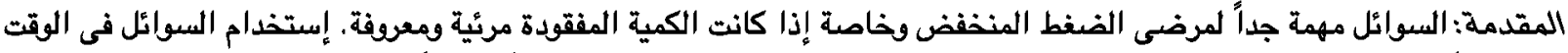

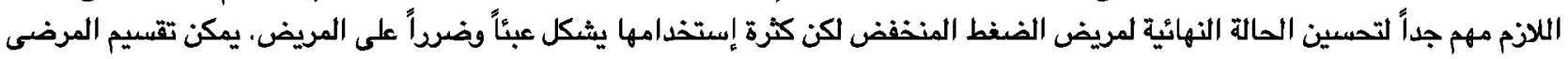

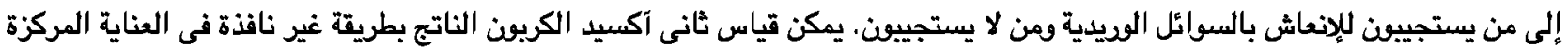

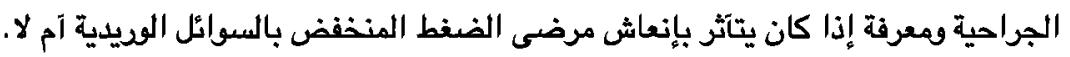 \\ الهدف من البحث: دراسة العلاقة بين ثانى آكسيد المخرج ومتوسط الضغط الثريانى كمؤشر للإستجابة اللسوائل الوريدية.

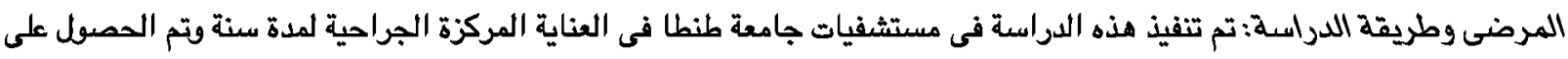

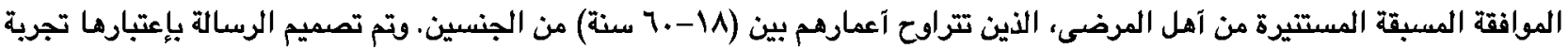 \\ سريرية مستقبلية.
}

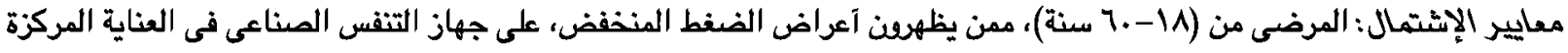
الجراحية ممن يستجييون للإنعاش عن طريق السوائل المويدية.

معايير الإستبعاد: عدم توافر الموافقة المستشيرة من آهل المرضى قبل عمل البحث ومرضى القلب والمرضى الذين يعانون من تدهود فى وظائف الكلى والكبد وإرتفاع درجة الحرارة.

خطة البحث: تم إعطاء السوائل الوريدية لمرضى الضغط والمنخفض وملاحظة علاقة ناتج آكسيد الكربون ومتوسط الضغط الشريانى. النتائج: ثانى آكسيد الكربون المخرج يزداد تدريجياً مع إعطاء السوائل الوريدية لمرضى الضغط المنففض.

الإستتاج: يمكن إستخدام والإعتماد على ثانى أكسيد الكريون المخرج كمؤشر لإستجابة مرضى الضغط المنففض السوائل الوريدية. 